\title{
Performance of sand-lime products made with plastic waste
}

\author{
Milena Nowek ${ }^{1, a}$ \\ ${ }^{1}$ Kielce University of Technology, Al. 1000-lecia PP 7, 25-314 Kielce, Poland
}

\begin{abstract}
The paper describes the studies on the sand-lime (silicate) masonry units modified with recycled plastics in various forms: regranulate, regrind and powder. The following materials were examined: high impact polystyrene (HIPS) and acrylonitrile butadiene styrene (ABS). The results of the functional properties tests, such as compressive strength, softening behavior, bulk density and water absorption are presented in the article. The microstructure of the products was analyzed using SEM and XRD methods.Obtained results show that the properties of modified product largely depend on the type, form and amount of used polymer. The highest compressive strength was achieved with $15 \%$ of HIPS regranulate in the product (by weight). ABS does not improve the strength of the sample, however, it does block the capillary action in the sand-lime product. The lowest softening coefficient was obtained in the sample modified with HIPS regranulate. The examined polymers contributed to decrease in bulk density of the samples as well as lowered their water absorption. The samples with pulverized polymer have the worst properties. All the results are compared with those of the traditional sand-lime bricks and sand-lime product modified with other additives. The analysis indicate that silicate masonry units with post-production and post-consumption plastic waste can possess interesting functional properties what brings a new potential possibility to dispose of still growing number of plastic waste.
\end{abstract}

\section{Introduction}

Sand-lime products (silicates) are environmentally friendly construction materials. Traditional silicates contain in their composition only sand, lime and water and their characteristic properties are obtained thanks to hydrothermal treatment during autoclaving process.

In recent years, much attention has been devoted to research on modified sand-lime products containing among other waste materials, such as waste molding sands, post reclamation dusts, hematite tailings, fly ashes, bottom ashes, copper tailings, foam glass as well as recycled plastics [1-8].

The overall purpose of the study was to improve certain characteristics of silicates and at the same time dispose of plastic waste.

It is known from the literature [8] that regranulate of high impact polystyrene has very beneficial effect on compressive strength of silicates.

Any kind of acting during processing of plastic waste, for example cutting or grinding, can cause changes in the material properties. Thanks to comprehensive research, changes in molecular structure after multiple processing of both pure and polluted polymers are well known. Multiple of processing, as well as heat treatment during a particular operation, result in degradation

\footnotetext{
${ }^{\mathrm{a}}$ Corresponding author: mnowek@tu.kielce.pl
}

of macromolecules of the polymer. Nevertheless, research has shown that there are grounds for wider than previously use of polyolefins recyclates for manufacturing of various products without reducing their quality requirements [9]. Plastic waste can be blended with virgin plastic in order to reduce cost without sacrificing their properties. The problem related to plastics wastes has increased tremendously since the use of plastics increased in most industrial, commercial and residential applications. Plastic waste causes severe environmental problems when incinerated or open burned on roadsides or in illegal dumpsites [10].

Mechanical recycling of plastics involves cleaning, sorting, cutting, shredding, agglomeration, pelletizing and finally reprocessing by injection molding, blowing or extrusion according to the required products [10]. High value of the recycled material justifies the incurred expenditures. The condition of proper material recycling is to obtain recyclates with good, repeatable and defined properties. Problems with the quality and repeatability of the properties of recyclates can be solved if the process of their recovery will be treated as a process of production of new materials, shaped in terms of their most efficient uses [11]. 


\section{Methodology}

In order to carry out laboratory tests of modified sandlime products, the author has prepared cuboidal samples with dimensions of $40 \times 40 \times 160 \mathrm{~mm}$. The samples were made in Silicates Production Plant in Ludynia. The sand for production of sand-lime products has to meet certain requirements concerning the minimum $\mathrm{SiO}_{2}$ content of $80 \%$, chemical composition and particle size. The sand used in the technological process has the grain size of $0-2 \mathrm{~mm}$. Grain size distribution of sand influences the mechanical properties of silicate materials. The sand is mixed with quicklime and water in appropriate proportions. The sand constitutes approximately $90 \%$ of the product weight, lime is approx. $7 \%$ and water $-3 \%$. In steel reactors, the process of lime slaking in silicate mass takes place. When exposed to water, quicklime is converted into slaked lime. As a result of elevated temperature derived from the reaction of lime slaking and alkaline environment the surface of sand grains loses its crystalline structure. In this way, the grains of sand get the proper form for further transformation into silicate in the later stages of the production process [12].

In the next stage, the author introduced to the sandlime mass $15 \%$ of polymer (per weight). The polymer was in the form of: high impact polystyrene (HIPS) regranulate, regrind and powder, as well as copolimer acrylonitrile-butadiene-styrene (ABS) regranulate.

HIPS is a lightweight material with high stiffness, which is impact and crack resistant. Polystyrene HIPS contains caoutchouc bound physically or chemically. Accordingly to the share of the caoutchouc, physical and mechanical properties of the material are different. Products made of polystyrene HIPS are used among others to make equipment cases, elements of lighting fixtures and in the food industry to manufacture of packaging.

ABS is a material with high hardness and impact resistance which has good insulating properties and is characterized by a high softening temperature. ABS is used in the production of machinery and equipment housing, interior elements of vehicles, various types of containers or elements of furniture [13].

The amount and type of used in the study polymers resulted from the previous research [8], which has shown a significant improvement in the compressive strength of sand-lime products containing $20 \%$ of HIPS regranulate and $30 \%$ of its regrind.

HIPS regranulate in the form of slightly flattened cylinders with the maximum dimension of $4 \mathrm{~mm}$ was used. HIPS regrind was added as irregular blades with various shapes and dimensions. HIPS had been previously pulverized to the grain size of $630 \mu \mathrm{m}$. ABS was used in the form of irregular cylinders with dimensions up to $3 \mathrm{~mm}$.

Next, all the components were precisely mixed with a small amount of additional water and then placed in steel molds. The specimens were compressed under the pressure of $20 \mathrm{MPa}$ and cured in industrial autoclaves under the following conditions: saturated water steam temperature equal to $203^{\circ} \mathrm{C}$ and pressure equal to 1.6
$\mathrm{MPa}$, total time of curing - 8 hours. Table 1 presents the qualitative and quantitative composition of the individual samples.

Table 1. Composition of the samples.

\begin{tabular}{|c|c|c|c|}
\hline Sample No. & Form of & $\begin{array}{c}\text { Share of } \\
\text { polymer } \\
\text { polymer in } \\
\text { the sample } \\
\text { weight [\%] }\end{array}$ \\
\hline 1 & $\mathrm{x}$ & $\mathrm{x}$ & $\mathrm{x}$ \\
\hline 2 & HIPS & regranulate & 15 \\
\hline 3 & HIPS & regrind & 15 \\
\hline 4 & HIPS & powder & 15 \\
\hline 5 & ABS & regranulate & 15 \\
\hline
\end{tabular}

\section{Results and discussions}

All the tests have been carried out on 6 specimens. Compressive strength test of dry samples indicated, that the value of this parameter strongly depends on the type of used polymer and its form. In the case of HIPS regranulate the value was the highest and equal to 32.04 $\mathrm{MPa}$, which is higher by almost $55 \%$ than the strength of the reference sample The other polymers has decrease the compressive strength of the silicate. The lowest strength equal to $2.84 \mathrm{MPa}$ was obtained for the samples with HIPS powder. HIPS powder constitutes a large part of the specimen (high volume fraction) and physically blocks the reactions between lime and silica. The pulverization of the regranulate might have a major impact on the deterioration of the properties of the material. Loose structure and many relatively large pores were observed. During hydrothermal curing all the polymers have partially melted down and to some extent filled the spaces between the other ingredients.

Previous studies performed by the author [8] indicated, that the addition of 10 and $20 \%$ of HIPS regranulate improves the compressive strength of such modified sand-lime products by respectively 43 and $163 \%$. The addition of HIPS powder in an amount of $10 \%$ resulted in decrease in the compressive strength by $70 \%$. The findings of the study on the use of mixed polypropylene and polyethylene regrinds are also interesting. PP and PE also improved the compressive strength of sand-lime products, however, their impact was slightly lower than the impact of high impact polystyrene.

There are known descriptions of the research on the use of HIPS regranulate as an additive for the autoclaved aerated concrete [14]. At 10\% of the regranulate in the sample weight, the compressive strength of the products slightly rises, but further addition of HIPS results in reduced strength. HIPS recyclate has been also tested as the additive in cement mortar [15]. Decilne in the compressive strength by $12 \%, 22 \%$ and $49 \%$ was obtained for mortar containing $10 \%, 20 \%$ and 50\% HIPS, respectively. Polymer-modified mortars with recycled ABS powder have been also investigated [16]. The compressive modulus increased at $8 \%$ and $15 \%$ but decreased at $25 \%$ of ABS in the mortar. The addition of ABS powder increases the porosity of the material. 
Softening-coefficient determines the destructive effect of water on building materials. The coefficient was calculated by dividing the compressive strength of a saturated sample by the compressive strength of a dry sample. For the sample containing HIPS regranulate the softening-coefficient has the highest value, while the lowest coefficient was noted for the sample with HIPS regrind. In this case, water absorption due to capillary action was the highest. The absorption of the other samples was lower than the absorption of the reference sample. Extremely low water absorption, equal to $1.59 \%$ was obtained for the sample containing ABS regranulate. The central part of the cross-section of this sample remained dry after 3 days of full immersion in water.

Added plastics in varying degrees influenced the decrease in the bulk density of of the sand-lime products. The lowest bulk density was achieved with the addition of HIPS powder. Table 2 presents the results of the compressive strength, softeningcoefficient, water absorption and bulk density of the samples.

Table 2. Tests results.

\begin{tabular}{|c|c|c|c|c|}
\hline 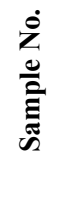 & 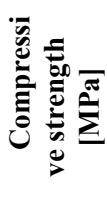 & 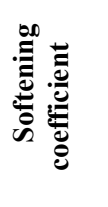 & 兰总 & 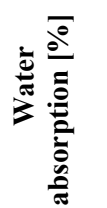 \\
\hline 1 & 20.7 & 0.87 & 1944 & 13.5 \\
\hline 2 & 32.0 & 0.96 & 1530 & 12.5 \\
\hline 3 & 17.0 & 0.56 & 1417 & 15.7 \\
\hline 4 & 2.8 & 0.61 & 1089 & 11.9 \\
\hline 5 & 13.7 & 0.71 & 1629 & 1.59 \\
\hline
\end{tabular}

The basic components of sand-lime products are hydrated calcium silicates, which bind together the grains of sand. Besides them in traditional sand-lime products also some residues of unreacted sand and lime as well as water and air in pores are present. The amount of particular phases has an impact on the mechanical strength of resulting products and their other properties. Stabilized compounds with crystalline structure and dimensions up to several tens of microns are obtained thanks to the hydrothermal treatment of the components of $\mathrm{CaO}-\mathrm{SiO}_{2}-\mathrm{H}_{2} \mathrm{O}$ system at the temperature exceeding $100^{\circ} \mathrm{C}$ [17]. Many years of research show that in the autoclaved sand-lime products mostly the following hydrated calcium silicates can be found: C-S-H (I), C-S-H (II), $11 \AA$ tobermorite, xonotlite and $\mathrm{C}_{2} \mathrm{SH}(\mathrm{A})$ [3].

The phase composition of the samples was characterized by XRD. X-ray diffractometry revealed the presence of quartz, calcium silicate and tobermorite $11 \mathrm{~A}$ in each specimen. XRD analysis of samples containing plastic waste indicated also presence of calcite in small amount. In addition, a large amount of an amorphous substance (C-S-H) in the modified products, which does not give sharp peaks, was present. The measurements were made using a monochromatic radiation of a wavelength corresponding to the emission line $\mathrm{K}$ of copper in the angular range of $5-90^{\circ}$, scale 2 .

The samples were also subjected to the SEM observation. The C-S-H phase is a configuration of hydrated calcium silicates with a different level of structural arrangement: $\mathrm{CaO}-\mathrm{SiO}_{2}-\mathrm{H}_{2} \mathrm{O}$, which emerges as a result of the reaction between calcium silicates and water. The tobermorite is the most ideal form of the C-S-H phase. It is a hydrated calcium silicate characterized by an arranged structure and specified interplane spaces $[18,19]$.

Figure 1 shows a grain of sand surrounded by the $\mathrm{C}-\mathrm{S}-\mathrm{H}$ phase, which then transforms into a higher and more perfect form, i.e. tobermorite. The tobermorite phase in a traditional silicate product appears in the form of blades with flat endings. Figure 2 is a diphractogram presenting the elemental structure of traditional silicate product [18]. A small amount of carbon comes from the preparation of the samples for SEM.

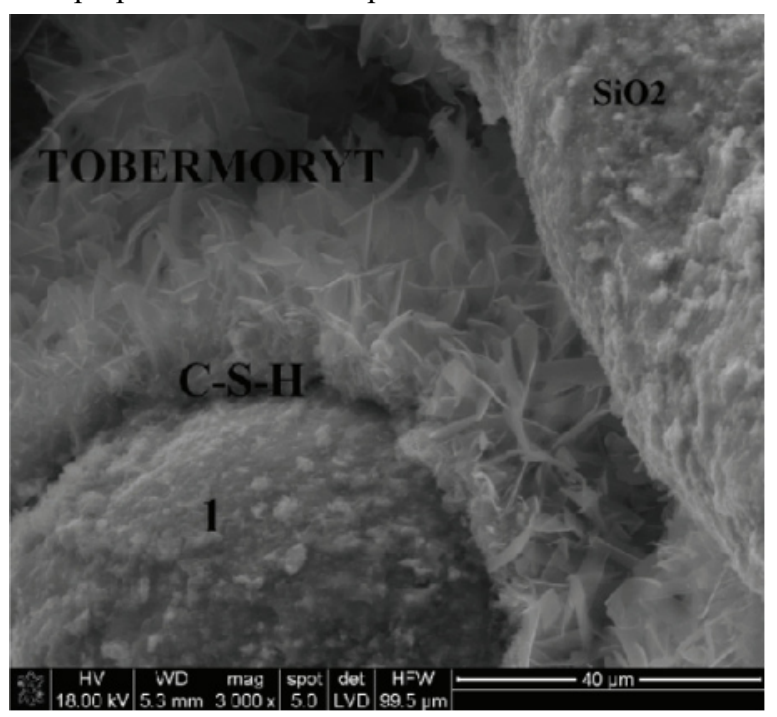

Figure 1. Microstructure of traditional silicate product [18].

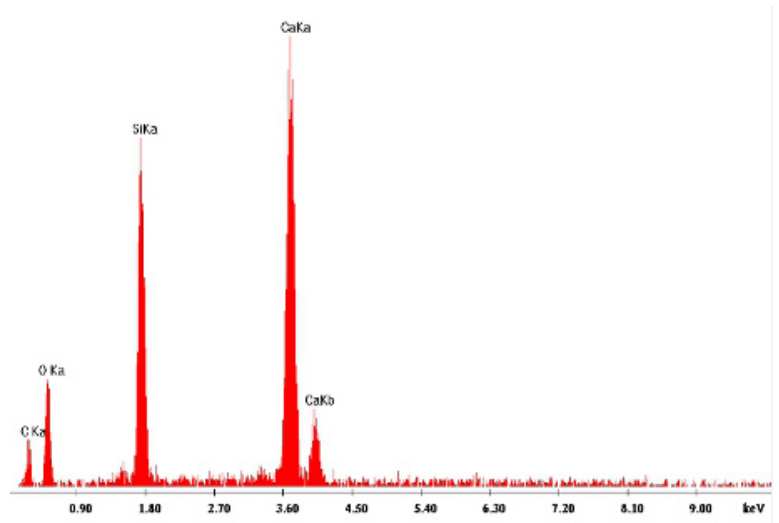

Figure 2. EDS spectrum of traditional silicate product in point 1 [18].

Observation of modified products revealed diverse forms of the synthesis products. In the samples with HIPS powder fibrous tobermorite, lathlike tobermorite and amorphous C-S-H phase broken by the polymer 
(Figure 3) were found almost exclusively. High compressive strength of silicate product containing HIPS regranulate is a result of good contact between the polymer and sand-lime mass ingredients. Well developed plate-like tobermorite and poorly crystallized C-S-H phase were found. In the sample with ABS regranulate hydrated calcium silicates with more and less ordered structure were found. Fibrous C-S-H phase was the predominant product.

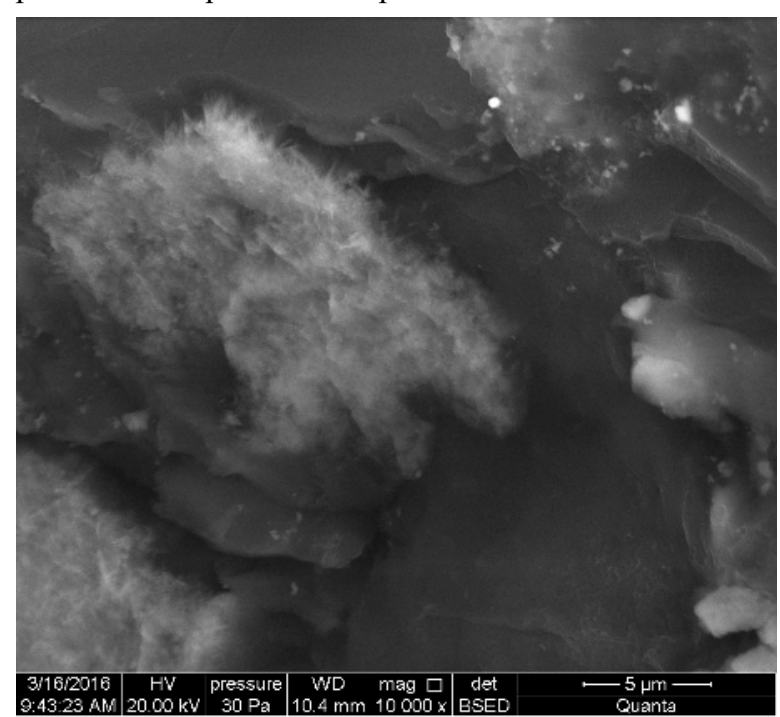

Figure 3. Microstructure of sample with HIPS powder $\mathrm{C}-\mathrm{S}-\mathrm{H}$ phase broken by polymer.

\section{Conclusions}

Introducing to the sand-lime mass properly selected recycled plastics can improve the compressive strength of the resulting products or significantly reduce water absorption.

Additives in the form of recycled plastics have a considerable influence on the characteristics of the modified sand-lime products, which depends on the type of polymer, form of recyclate and its quantity in the sample. The biggest impact on the compressive strength increase has HIPS regranulate, while ABS regranulate significantly reduces capilary action in the products. Obtained results show that the properties of modified product largely depend on the type, form and amount of used polymer. The highest compressive strength was achieved with $15 \%$ of HIPS regranulate in the product (by weight). ABS does not improve the strength of the sample, however, it does block the capillary action in the sand-lime product. The lowest softening coefficient was obtained in the sample modified with HIPS regranulate. The examined polymers contributed to decrease in bulk density of the samples as well as lowered their water absorption. The samples with pulverized polymer have the worst properties.

\section{References}

1. Z. Pytel, Archives of Foundry Engineering, 10 Special Issue 2(2010)

2. Y. Zhao, Y. Zhang, T. Chen, Y. Chen, S. Bao, Const. and Build. Mat. 28, 450-455 (2012)

3. S. Wolfke, Technologia wyrobów wapiennopiaskowych. Arady, Warszawa (1986)

4. Z. Pytel, Ceramic Mat., 60, 4 (2008)

5. Y. Fang, Y. Gu, Q. Kang, Q. Wen, P. Dai, Const. and Build. Mat. 25, 867-872 (2011)

6. R. Dachowski, I. Jasińska, Archives of the Institute of Civil Engineering, 13 (2012)

7. I. Jasińska, R. Dachowski, Praca zbiorowa pod redakcją Joanny Bzówki pt. Badania doświadczalne i teoretyczne w budownictwie, monografia (2012)

8. M. Nowek, Tech. Transactions. Czasopismo Techniczne, 1-B (2014)

9. praca zbiorowa pod redakcją prof. Dr hab. Andrzeja K. Błędzkiego, Recykling materiałów polimerowych, Wydawnictwa NaukowoTechniczne, Warszawa (1997)

10. S. El-Haggar, Sust. Indust. Design and Waste Managem. (2007)

11. J. Kijeński, A. K. Błędzki, R. Jeziórska, Odzysk i recycling mat. Polimer., PWN (2011)

12. J. Jasiczak, Budownictwo Ogólne Tom 1 Materiały i wyroby budowlane, rozdział 7, "Wyroby z zaczynów, zapraw i betonów”, Arkady, Warszawa (2005)

13. J. Pielichowski, A. Puszyński, Chemia polimerów. Wydawnictwo Naukowo-Techniczne TEZA, Kraków (2004)

14. R. Dachowski, S. Kapała, Materiały Budowlane $\mathbf{1 2}$ (2015), p. 18-20

15. R. Wang, C. Meyer, Cement \& Concrete Composites 34 (2012) p. 975-981

16. A. Palos, N.A. D'Souza, C.T. Snively, R.F. Reidy, Cement and Concrete Research 31 (2001), p. 1003-1007

17. E. Szymański, Technologia materiałów budowlanych. Wydawnictwo Politechniki Białostockiej, Białystok (2003)

18. R. Dachowski, A. Stępień, Procedia Engineering 21 (2011) p.1173-1178

19. W. Kurdowski, Chemia cementu i betonu, Wydawnictwo Naukowe PWN, Warszawa (2010) 